\title{
Effect of Takradhara in Children with Attention Deficient Hyperactivity Disorder (ADHD)
}

\author{
Research Article
}

\section{Ragamala KC ${ }^{1^{*}}$, Pravat Kumar Dash ${ }^{2}$}

1. Assistant Professor, Department of Kaumarabhritya, SV Ayurvedic College, Tirupati. Andhra Pradesh 2. Professor, HOD, Dept. Of Kaumarabhritya, Yaswanth Ayurvedic College, Kodoli, Kolhapur, Maharastra.

\begin{abstract}
ADHD is a complex neurobehavioral psychosomatic disorder, which affects millions of children and often persists into adulthood. According to the 4th edition, American Psychiatric Association's Diagnostic and Statistical Manual (DSM-IV criteria), the core symptoms of ADHD are 1) inattention 2) hyperactivity and 3) impulsivity. In Ayurveda it occurs due to vibramsha of Dhee (rational thinking), Dhriti (intellect / retaining power of the mind), Smriti (memory) which results into improper contact of the senses with their objectives and give rise to inattention, hyperactivity and impulsivity. In modern sciences, treatment predominantly relies on prescribing stimu-lant medications and psychosocial therapy. Stimulant drugs used to treat ADHD are associated with side effects like cardiovascular events etc. Therefore Ayurvedic literature explains many treatment modalities which are safe and effective in various disorders, among which Shirodhara (Takra processed with Brahmi, Jatamamsi, Vacha and Aswagandha) is a procedure which is widely used in psychosomatic disorders and there is a need to standardize this procedure as a safest treatment in children. Hence an effort is made to study the effect of Takradhara in Attention- Deficit Hyperactivity Disorder.

So to evaluate the effect of Takradhara in ADHD, 40 children aged $7-12$ years who were fulfilling the inclusion criteria and diagnostic criteria were selected from Kaumarabhritya OPD and IPD of S.V.Ayurvedic College \& Hospital, Tirupati. Takradhara was done for 14 days and then again repeated after every two months for 3 consecutive sittings. The cases were recorded as per the case sheet and observations were recorded. Symptoms were scored and statistically analyzed for any change before and after treatment. In the group statistically highly significant change $(p=<0.001)$ was observed in the symptoms of ADHD.
\end{abstract}

Keywords: Attention- Deficit Hyperactivity Disorder (ADHD), Ayurvedic view, Takradhara and its effects.

\section{Introduction}

With the advancement in day today's human life the diseases are also advancing. Due to more stressful and speedy life, the Psychiatric illness are broadening in adults as well as in children, among which ADHD is most common wide spread psychiatric disease affecting children in all over the world. The current opinion estimates its preva-lence in Indian children is approximately 3 to $4 \%$, the roughly the same percentage as in the western population. Boys are more affected than girls in 6:1 ratio. It is usually diagnosed at 3-4years of age. As per the DSM-IV criteria (1), these children will have difficulty in following the instructions and sustaining attention, often seem not to listen to what is being said, lose items frequently, are easily distracted, are fidgety, have a difficult time remaining and often engage in physically dangerous activities, does not remain in their seats in school, have difficulty awaiting their turn, impulsively blurt out

*Corresponding Author:

Ragamala K C

Assistant Professor, Department of Kaumarabhritya,

SV Ayurvedic College, Tirupati - 517507

Andhra Pradesh

E-mail ID:pnragkc@gmail.com answers to questions, shift rapidly from one uncompleted activity to another, talk excessively, intrude on others.(3)

Affected children commonly experience academic underachievement, problems with interpersonal relationships with family members and peers, and low self-esteem. They have a hard time in controlling their impulses and regulating their activity, attention. In brief this picture of the disease can be correlated with the few lakshanas of Manasa Vikaras described by Acharya Charaka which occur due to defects in the volitional power of the Manas i.e. the Buddhi or its constituents, the Dhee, Dhriti and Smriti. Along with Manasika doshas (Rajas and Tamas), Shareerika doshas (Vata, Pitta, Kapha) play a role in causing psychosomatic disorders, especially Vata dosha deranges the functions of Manas leading to Dhee, Dhriti and Smritivibhramsha. In Ayurvedic classics there is no exact disease found similar to ADHD but some references regarding abnormal behaviors like Anavasthita Chittatva, Manovibhrama, Buddhivibhrama, Smritivibhrama, Sheelavibhrama, Cheshtavibrama, and Acharavibhrama are found scattered in texts which resemble with the features of ADHD (8). Though these terms have been mentioned collectively under the description of Unmada Vyadhi, when considered individually they closely resemble 
with some of the clinical features of ADHD.

An understanding of the etiological aspects of ADHD may provide better planning of the treatment and prevention. The few etiological factors of ADHD identified as abnormalities in structures of brain (anterior cingulate cortex, the dorsolateral prefrontal cortex and basal ganglia), children with ADHD have approximately a 5-10\% reduction in these brain structures, (5) abnormalities in brain functions (cognitive dys-function) and abnormalities in Neurochemical brain system i.e. the Neurotransmitters like Dopamine (DA) and Norepinephrine (NE) are implicated in the pathophysiology of ADHD. (7)

As per Ayurveda - The Adhisthana of all the Indriyas is Shira. Chakrapani has mentioned "Indriyadhisthanam Manasa Karma" - controlling of Indriyas is the Karma of Manas. The chief location of Vata is upper portion of Mastiska (Atharvaveda). It is also the main seat of Prana Vayu which controls Manas.

Thus the ADHD can be compared and treated similar to that of Manasa Vikaras and overall when the pathophysiology of the disease is considered, both sciences emphasize that adhistana of disease is Shira (Head), hence choosing Shirodhara may be more appropriate in this study. Shirodhara is included under the banner of Murdha taila in Ayurveda, pouring of liquids like medicated Kashayas, Ksheera, Takra, Taila etc. on the forehead in-a-rhythmic pattern for a stipulated time is called as Shiroseka or Shirodhara. Dhara is not only used in psychic diseases but also used in psychosomatic diseases. (9)

In the study Takra processed with Brahmi, Jatamamsi, Vacha, Aswagandha churnas was taken for Shirodhara. Takradhara causes the pacification of vitiated Vata, it is Indriya Prasadana, produces relaxing effect, enhance the alertness and concentration abilities, improves cerebral function and anxiolytic action. (2)

\section{Aims and Objectives}

To evaluate the effects of medicated Takradhara in reducing the clinical features of Attention Deficit Hyperactivity Disorder.

\section{Materials and methods}

The materials and methods used and the modifications made was based on easy availability of the drugs, feasibility of the methods, available literature, traditional experiences and expert opinions.

Literary data Literary data was collected from different sources-Library, Classical texts of Ayurveda and modern texts including digital media, relevant articles and internet.

Source of data- For about 40 children aged between 7-12years were randomly selected for the study from OPD and IPD of Department of Kaumarabhrithya, S.V. Ayurvedic Hospital, Tirupati and also from local schools of Tirupati town.

\section{Selection of patients:}

The teachers in-charge of individual class were enquired about the academically under achieving students. Then such students were identified by the teachers, and features of ADHD as mentioned by DSMIV were examined.
Those fulfilling the DSM-IV criteria for diagnosis of ADHD were selected. The parents of the children were contacted and the diagnosis was confirmed after a detailed history taking from the parents. Those coming in the exclusion criteria were excluded.

\section{Method of study}

40 children aged between 7-12years were randomly selected and were treated with Takra dhara (Takra processed with few medhya drugs like Brahmi, Jatamamsi, Vacha, Aswagandha churnas ) for about 30 - 45 minutes for 14 days and then again repeated after every two months for 3 consecutive sittings.

Counseling: Counseling for both Parents and Guardian was given explaining the nature of disorder with reassurance and the patients were helped to deal with emotional as well as behavioral problems.

\section{Diagnostic Criteria}

For the diagnosis of ADHD and for assessment of ADHD children, a DSM-IV criteria was adopted.

\section{Inclusion Criteria}

- School going children aged between 7-12 years of age with poor academic achievements, poor concentration, increased distractibility, motor restlessness are Included in the study.

- Children fulfilling the DSM-IV criteria for diagnosis of ADHD.

\section{Exclusion Criteria}

- Children under other medications or interventions such as behavior therapy are excluded from the study.

- Children with mild to severe mental retardation conduct disorders, Pervasive disorder and other Psychotic disorders are excluded.

- Children with chronic ailments like tuberculosis, malignancy etc. are excluded.

\section{Duration:}

The period of study will be for six months. (3 consecutive sittings with an interval of two months).

\section{Follow up of the Study:}

- All the cases are followed up with an interval of two months between each sitting for the progress or changes during treatment.

- Follow up will be for one month after completion of treatment also.

\section{Assessment Criteria:}

The assessment is done with the help of subjective parameters.

Thorough clinical assessment was done to all the patients before treatment, after treatment and after follow up by a self prepared scale on the basis of DSM IV criteria.

\section{Subjective criteria:}

DSM-IV criteria for diagnosis of children with ADHD were used for the subjective scoring of the symptoms of the disease. 
Inattention, hyperactivity and impulsivity were measured by obtaining a four point rating of the DSMIV items.

\section{Scoring Of Clinical Symptoms Of ADHD :}

Inattention, hyperactivity and impulsivity were measured by obtaining a four point rating of the DSMIV items. The scoring was done ranging from 'never' to 'very often' as given below.

- Never 0

- Often 1
- Quite often 2

- Very often 3

\section{Observations and Results}

Analysis was done before and after treatment procedure based on clinical features of the ADHD patients and scoring was given as per the scales used for the study. as follows:

Results:

Table 1: Showing the results on various parameters taken for the study

\begin{tabular}{|c|c|c|c|c|c|c|c|c|c|}
\hline \multirow[t]{2}{*}{ Parameters } & \multirow[t]{2}{*}{$\bar{n}$} & \multicolumn{2}{|c|}{ Mean } & \multirow[t]{2}{*}{$\%$} & \multicolumn{2}{|c|}{ SD } & \multirow[t]{2}{*}{$\overline{\mathrm{SE}}$} & \multirow[t]{2}{*}{ 't' value } & \multirow[t]{2}{*}{ 'p' value } \\
\hline & & BT & $\overline{\mathbf{A T}}$ & & BT & $\overline{\mathbf{A T}}$ & & & \\
\hline $\begin{array}{l}\text { Fail to give } \\
\text { details }\end{array}$ & 40 & 2.80 & 1.05 & $62.5 \%$ & 0.41 & 0.50 & 0.069 & 25.238 & $<0.001$ \\
\hline $\begin{array}{l}\text { Difficulty in } \\
\text { sustaining } \\
\text { attention }\end{array}$ & 40 & 2.65 & 1.03 & $61.5 \%$ & 0.48 & 0.58 & 0.07 & 20.961 & $<0.001$ \\
\hline $\begin{array}{l}\text { Not seem to } \\
\text { listen }\end{array}$ & 40 & 2.73 & 1.18 & $56.77 \%$ & 0.45 & 0.50 & 0.08 & 19.457 & $<0.001$ \\
\hline $\begin{array}{l}\text { Fails to follow } \\
\text { instructions and } \\
\text { finish work }\end{array}$ & 40 & 2.73 & 1.28 & $53.11 \%$ & 0.45 & 0.45 & 0.08 & 18.201 & $<0.001$ \\
\hline $\begin{array}{l}\text { Difficulty in } \\
\text { organizing tasks }\end{array}$ & 40 & 2.68 & 0.78 & $70.89 \%$ & 0.47 & 0.42 & 0.07 & 24.220 & $<0.001$ \\
\hline $\begin{array}{l}\text { Dislikes, avoids or } \\
\text { is reluctant to } \\
\text { engage in tasks }\end{array}$ & 40 & 2.80 & 1.05 & $62.5 \%$ & 0.41 & 0.50 & 0.06 & 25.238 & $<0.001$ \\
\hline $\begin{array}{l}\text { Often looses } \\
\text { things }\end{array}$ & 40 & 2.68 & 0.70 & $73.88 \%$ & 0.47 & 0.52 & 0.06 & 29.536 & $<0.001$ \\
\hline $\begin{array}{l}\text { Often easily } \\
\text { distracted }\end{array}$ & 40 & 2.63 & 0.73 & $72.24 \%$ & 0.49 & 0.51 & 0.10 & 19.000 & $<0.001$ \\
\hline Often forgetful & 40 & 2.68 & 1.03 & $61.56 \%$ & 0.47 & 0.58 & 0.105 & 15.759 & $<0.001$ \\
\hline Often fidgets & 40 & 2.70 & 1.18 & $56.66 \%$ & 0.46 & 0.50 & 0.101 & 15.069 & $<0.001$ \\
\hline $\begin{array}{l}\text { Often leaves seat } \\
\text { in classroom }\end{array}$ & $\overline{40}$ & 2.68 & 0.78 & $70.89 \%$ & 0.47 & 0.4 & 0.09 & 20.349 & $<0.001$ \\
\hline $\begin{array}{l}\text { Often runs about } \\
\text { or climbs }\end{array}$ & 40 & 2.75 & 0.8 & $69.09 \%$ & 0.44 & 0.36 & 0.08 & 22.033 & $<0.001$ \\
\hline $\begin{array}{l}\text { Often has } \\
\text { difficulty in } \\
\text { playing }\end{array}$ & 40 & 2.70 & 0.78 & $71.48 \%$ & 0.46 & 0.42 & 0.07 & 25.666 & $<0.001$ \\
\hline $\begin{array}{l}\text { Often "on the go" } \\
\text { or acts as of } \\
\text { "driven by the } \\
\text { motor" }\end{array}$ & 40 & 2.65 & 0.80 & $69.81 \%$ & 0.48 & 0.41 & 0.07 & 24.222 & $<0.001$ \\
\hline $\begin{array}{l}\text { Often talks } \\
\text { excessively }\end{array}$ & 40 & 2.75 & 0.85 & $69.09 \%$ & 0.44 & 0.36 & 0.04 & 39.551 & $<0.001$ \\
\hline $\begin{array}{l}\text { Often blurts out } \\
\text { answers before } \\
\text { questions }\end{array}$ & 40 & 2.68 & 0.75 & $72.01 \%$ & 0.53 & 0.44 & 0.07 & 25.666 & $<0.001$ \\
\hline $\begin{array}{l}\text { Has difficulty in } \\
\text { awaiting turn }\end{array}$ & 40 & 2.05 & 0.75 & $68.48 \%$ & 0.78 & 0.44 & 0.07 & 20.961 & $<0.001$ \\
\hline $\begin{array}{l}\text { Often interrupts or } \\
\text { intrudes on others }\end{array}$ & 40 & 2.23 & 0.85 & $61.88 \%$ & 0.58 & 0.48 & 0.07 & 17.737 & $<0.001$ \\
\hline
\end{tabular}


Total Effect of Therapy

Total effect of therapy on 40 patients of ADHD was calculated by taking the mean of $\%$ of relief based on the four point rating of the DSM-IV items and categorized into:

DSM IV criteria (54 points)

- Cured -When the relief is partially observed between $91 \%$ to $100 \%$ and scoring points less than 10 in clinical symptoms collectively considered as cured.

- Marked improvement - When the relief is partially observed between $75 \%$ to $90 \%$ and scoring points between $10-20$ in clinical symptoms.

- Moderate improvement - When the relief is partially observed between $50 \%$ to $75 \%$ and scoring points between 21-30 in clinical symptoms.

- Mild improvement - When the relief is partially observed between $25 \%$ to $50 \%$ and scoring points between 31- 40 in clinical symptoms.

- Unchanged - When the relief is partially observed between $<25 \%$ and scoring points between $41-54$

- in clinical symptoms.

Table 2: Showing the overall result of the therapy

\begin{tabular}{|l|l|l|}
\hline \multicolumn{1}{|c|}{ Result } & \multicolumn{1}{c|}{ No. of Patients } & \% \\
\hline Complete & 0 & 0 \\
\hline Marked & 0 & 0 \\
\hline Moderate & 14 & 35 \\
\hline Mild & 26 & 65 \\
\hline Unchanged & 0 & 0 \\
\hline
\end{tabular}

Figure 1: Showing the Overall Result

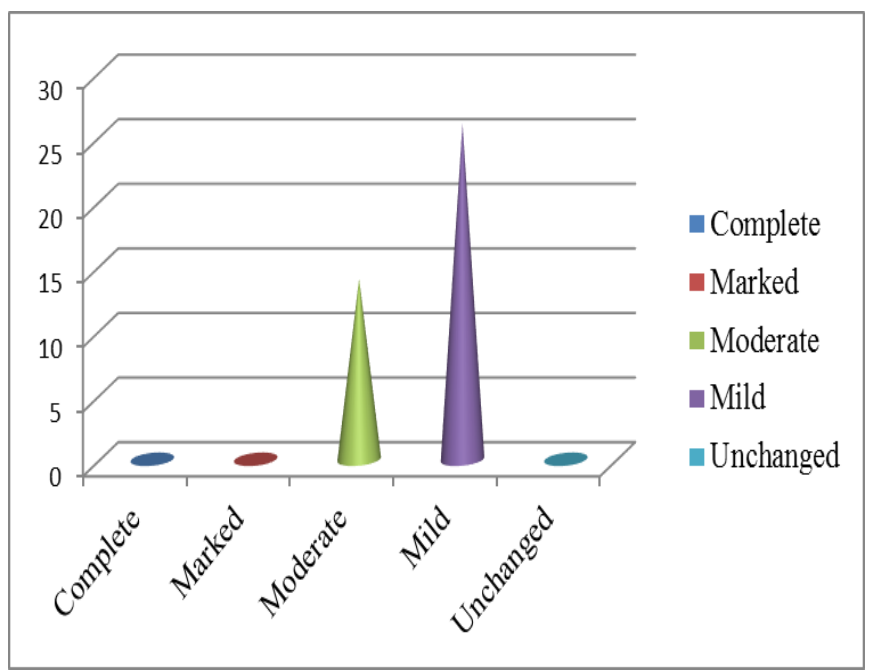

In a sample size of 40 patients, 14 patients (35\%) were shown Moderate improvement, 26 patients $(65 \%)$ showed Mild improvement.

\section{Discussion}

Attention Deficit Hyperac-tive Disorder (ADHD) is a syndrome with complex of impairments in developmental self-management system of the brain. It is identified to affect preschoolers, adolescents and even adults, causing impairments in school, home, and in the community. Modern medications are found to have many complications. (4) Therefore there is a wide scope of research in Ayurveda to find out safest remedy in the management of this disease.

Since the disease ADHD is being considered as Manasa Vikara with involvement of Vata Dosha and Manas, hence chikitsa alleviating tridoshas particularly Vata and having effects on the Manas should be preferred. Bahya Prayogas like Shirodhara will be more beneficial to pacify the Vata Dosha and supports the Manas to regulate the mental activities, and thus in this study an effort was made to reduce the symptoms of ADHD through Shirodhara especially Takra processed with Medhya drugs (Brahmi, Jatamamsi, Vacha, and Aswagandha) was used.

The seat of Manas has been described as "Shirastalwantargat' by Acharya Bhela and this is also the position of brain mainly the cerebral cortex. The normality and abnormality of both the Manas and the brain can be inferred from their functions. The therapies and medications which are said to be acting on the Manas exert their effect on the CNS.

The important areas of the brain, centre for judgment, centre for intellect, centre for speech etc are situated in frontal area, with Takradhara relaxation of the frontalis muscle occurs, tends to normalize the activities of the entire body, improve cerebral functions through increased cerebral blood flow, enhances concentration abilities and decrease in activity of sympathetic nervous system thus lowering the hyperactivity and impulsive behavior found in ADHD children. Thus relaxing mind and body.

Shirodhara may help to stimulate many vital areas like Sthapani Marma and Agna Chakra, which are seated in Bhrumadhya and are sthana of Manas. Slight stimulation of these spots may have beneficial effect on the mind and body, due to their connection with higher centers of brain.

Out of the 40 patients 14 patients (35\%) showed moderate improvement and 26 patients $(65 \%)$ showed mild improvement in their symptoms. Overall picture of the results obtained in the study shows that Takradhara helps to reduce the symptoms of ADHD.

\section{Probable Mode of Action of Takradhara(10)}

The Shirodhara is effective in following two ways

1) Medicaments used and its therapeutic effect

2) Effect of the procedure 
Figure 2: Showing the Probable mode of action of Takradhara

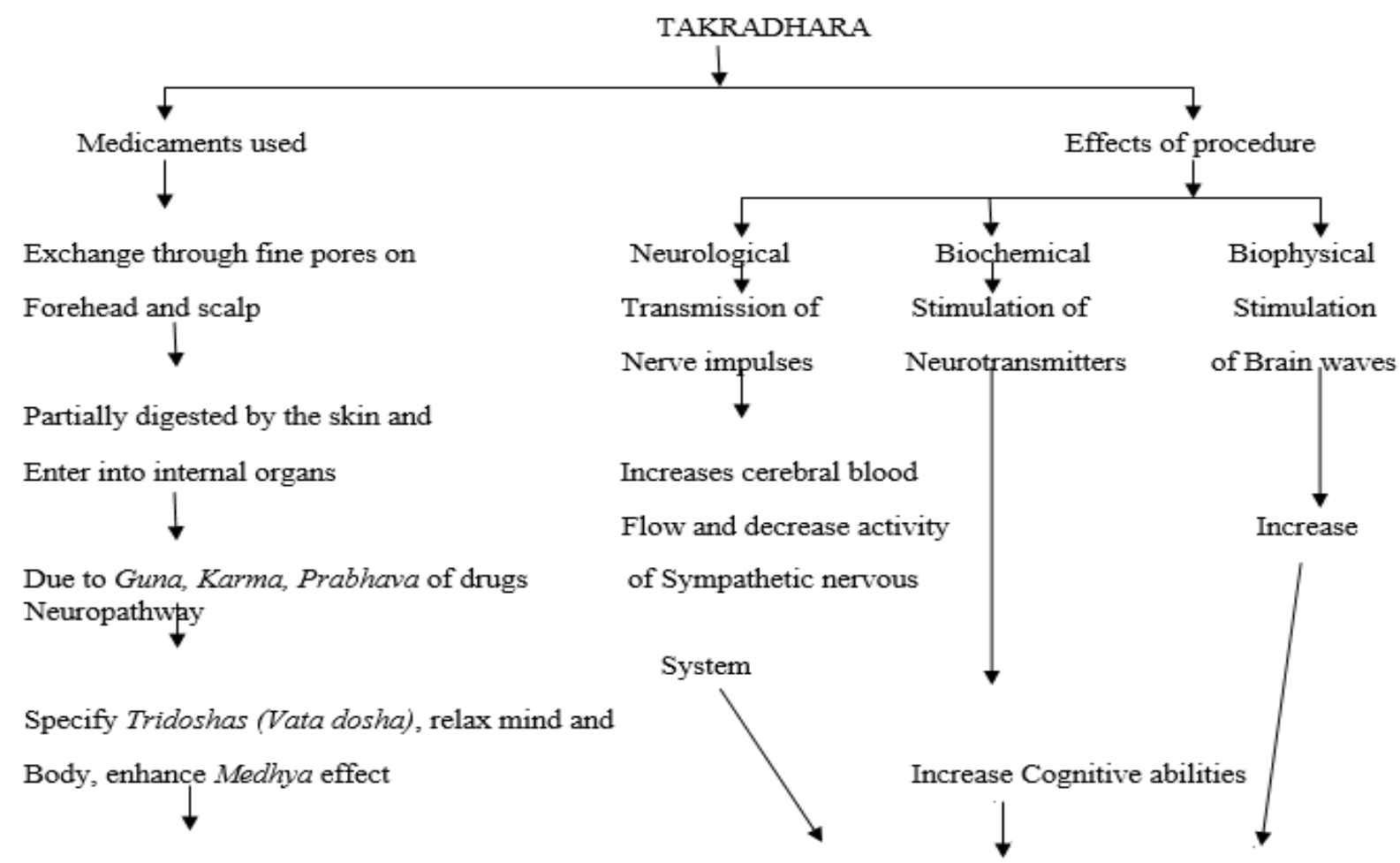

Reduce symptoms of $\mathrm{ADHD}$

Lowering the Hyperactivity and Impulsivity and

Increases Concentration

\section{Conclusion}

ADHD is a neurobehavioral disorder with decreased attention and impulsive behavior, affecting the school aged children especially more commonly seen in boys. The symptoms of ADHD are caused by a neurological dysfunction within the brain. The medicaments used are usually stimulants but they have several side effects.

The ADHD can be compared and treated similar to that of Manasa Vikaras. Among the Ayurvedic treatments, Shirodhara with medicated Takra stands as an important therapeutic procedure which can be very beneficial in reducing the core symptoms of ADHD.

External stimulus through Shirodhara calms the mind and relaxes entire body by pacifying vitiated Vata dosha, alleviating Chintadi Manasika Bhavas and it also helps to increase cerebral functions thus decreasing hyperactivity and impulsive behavior in ADHD (Attention Deficit Hyperactive disorder).

\section{References}

1. Brown TE: Developmental Complexities of Attention Disorders, in ADHD Comorbidities: Handbook for ADHD Complications in Children and Adults, First Edition. Edited by Brown TE. Washington DC, American Psychiatric Publishing, 2009, pp 3-22.

2. Singal HK, Neetu, Kumar A, and Rai.M. Ayurvedic approach for improving reaction time of attention deficit hyperactivity disorder affected children Ayu. 2010 July- Sep; 31(3): 338 - 342. http:// dx.doi.org/10.4103/074 - 8520.77169.

3. Parthasarathy $A$ and Menon PSN, IAP TEXT BOOK OF pediatrics, $4^{\text {th }}$ edition, 2009, 1049-51p.

4. Robin, AL: ADHD in Adolescents: Handbook for ADHD Complications in Children and Adults, First Edition. Edited by Brown TE. Washington DC, American Psychiatric Publishing, 2009, pp 69-80.

5. Shaw P, Malek M, Watson b, Sharp W, Evans A, Greenstein D. Development of cortical surface area and gyrification in attention deficit hyperactivity disorder. Biol Psychiatry 2012 Aug 1; 72(3): 191-7. http:// dx.doi.org/10. 1016 / j. biopsych. 2012.01.031.

6. Behrman, Kliegman, Jenson, Nelson Textbook of Pediatrics, 18th edition, 2007, 146-150 p.

7. Behrman, Kliegman, Stanton, Nelson Textbook of Pediatrics, 20th edition, 2016, 296-297p.

8. Kashinath Shastry, Gorakhnath Chaturvedi, Charaka Samhitha of Agnivesha, Nidana sthana, Chaukhamba Bharatiya Academy, Varanasi, 2011, $656 \mathrm{p}$.

9. Kashinath Shastry, Gorakhnath Chaturvedi, Charaka Samhitha of Agnivesha, Sutra sthana, Chaukhamba Bharatiya Academy, Varanasi, 2011, 127 p.

10. Pavana J, Manoj Sankaranarayan, Keraliya Cikitsa Paddhatih, Ayurvedi educational and charitable trust, Kanyakumari, TN, 2010,163-166 p. 